\title{
Regional renewable energy: A string of legal and financial challenges
}

\author{
Citation for published version (APA):
}

Peeters, M., \& Schomerus, T. (2014). Regional renewable energy: A string of legal and financial challenges. In M. Peeters, \& T. Schomerus (Eds.), Renewable energy law in the EU: Legal perspectives on bottom-up approaches (pp. 281-316). Edward Elgar Publishing. New Horizons in Environmental and Energy Law series https://doi.org/10.4337/9781783473199.00024

Document status and date:

Published: 01/01/2014

DOI:

10.4337/9781783473199.00024

Document Version:

Accepted author manuscript (Peer reviewed / editorial board version)

\section{Please check the document version of this publication:}

- A submitted manuscript is the version of the article upon submission and before peer-review. There can be important differences between the submitted version and the official published version of record.

People interested in the research are advised to contact the author for the final version of the publication, or visit the DOI to the publisher's website.

- The final author version and the galley proof are versions of the publication after peer review.

- The final published version features the final layout of the paper including the volume, issue and page numbers.

Link to publication

\footnotetext{
General rights rights.

- You may freely distribute the URL identifying the publication in the public portal. please follow below link for the End User Agreement:

www.umlib.nl/taverne-license

Take down policy

If you believe that this document breaches copyright please contact us at:

repository@maastrichtuniversity.nl

providing details and we will investigate your claim.
}

Copyright and moral rights for the publications made accessible in the public portal are retained by the authors and/or other copyright owners and it is a condition of accessing publications that users recognise and abide by the legal requirements associated with these

- Users may download and print one copy of any publication from the public portal for the purpose of private study or research.

- You may not further distribute the material or use it for any profit-making activity or commercial gain

If the publication is distributed under the terms of Article $25 \mathrm{fa}$ of the Dutch Copyright Act, indicated by the "Taverne" license above, 


\title{
Regional renewable energy: a string of legal and financial challenges
}

\author{
Marjan Peeters and Thomas Schomerus ${ }^{1}$
}

(Final draft)

Published in:

Marjan Peeters, Thomas Schomerus, Renewable Energy Law in the EU. Legal Perspectives on Bottom-up Approaches, Edward Elgar, Cheltenham, UK 2014, p. 10-34 (Leuphana University research)

(Final draft)

See ElgarOnline https://www.elgaronline.com/view/9781783473182.00024.xml

\footnotetext{
${ }^{1}$ Thomas Schomerus and Marjan Peeters were at the time of writing of this chapter members of the research team in the projekt Innovation Incubator, Act. 1.1/CT EnERgioN, sponsored by the European Union with funds from the European Regional Development Fund (ERDF) and by the state of Lower Saxony.
} 


\section{Introduction}

The target of 20 per cent for the overall share of energy from renewable sources in the European Union by 2020, and the need for a further increase of renewable energy consumption towards 2030 call for a major transformation in society. Above and beyond the technological challenges such as developing efficient renewable energy generation, improving the grid - particularly with regard to incorporating volatile energy sources - and developing storage techniques for temporary renewable energy surplus, a string of societal and, more specifically, legal challenges need to be explored. The previous chapters of this book have focused on legal aspects of the transition towards renewable energy, specifically exploring new questions from regional government perspectives. Part of this legal exploration includes the legal aspects of the role of finance, both in terms of supporting renewable energy and of engaging local involvement. Another major part addresses the competences of, and decisionmaking by regional governments. This concluding chapter aims to bridge the findings of the contributing authors and provides overarching observations. We construct our findings around three main themes:

[bl] - the relevance of the EU legal renewable energy framework for regional governments (Section 2);

- legal aspects of finance (Section 3), firstly with attention to support mechanisms (Section 3.1), and then to potential paths for financial participation by citizens and local communities in renewable energy projects (Section 3.2); and

- $\quad$ the authorization of renewable energy projects (Section 4).[/list]

Section 5 concludes the book.

\section{The EU legal framework and its relevance for reginoal authorities}

2.1 The Complex, Yet Fragmented EU Framework with Regard to Regional Governments

The EU climate and energy legal framework is relatively new and, at the same time, already very complex. The Renewable Energy Directive asks for a major change in each Member 
State, and the legal framework contains several obligations for Member States which, having been implemented, will affect the situation in regional governments. National governments were required to develop National Renewable Energy Action Plans and, any Member State not on track with its indicative trajectory towards the target for 2020, must provide the European Commission with an amended Plan. ${ }^{2}$ Apart from that, in order to implement the Directive, national legislation had to be adopted. Such rules can apply to the support of renewable energy, the authorization of renewable energy projects and provisions concerning access to and operation of the grid. This all leads to a package of laws at national level, intended to implement EU law and ultimately aiming at the 20 per cent renewable energy share by 2020. As explained by Moritz Meister in Chapter 6, specific domains of energy law relevant for renewable energy may be highly detailed and complex, which means, for instance, that the extent to which law serves the possibilities of regional virtual power plants is not easy to determine. One can wonder to what extent regional governments are capable of understanding and implementing the legal rules relevant for renewable energy, and, moreover, whether citizens' initiatives for decentralized generation of renewable energy can deal with the complex package of new law. Interpretation and application of new rules is often surrounded with uncertainties, and, moreover, this cannot take place in isolation. One can, for instance, pose the questions to what extent EU and international trade law hinder local governments in promoting locally generated renewable energy (see Chapter 3 by Hartmut Kahl), how the Aarhus Convention plays a role in renewable energy policies (Chapter 2 by Marjan Peeters and Thomas Schomerus), or to what extent EU financial rules determine the feasability or the transaction costs of regional renewable energy initiatives (see Chapter 12 by Lars Holstenkamp). One rather obvious overall conclusion is that applying the new rules for renewable energy will involve experimentation and a learning process, and that, given the concerns at stake, courts will be increasingly addressed in the search for clarity as to the applicable rules and for help in solving legal conflicts.

Although the first contours have emerged, the future of the EU legal framework remains uncertain. Despite the fact that no legal decision-making has yet occurred regarding Member States' targets post 2020, the European Commission disclosed the new energy and climate objectives for 2030 on 22 January 2014. While a binding overall EU target of 27 per cent was proposed, according to the Commission's view, there will no longer be any binding

\footnotetext{
${ }^{2}$ Article 3(2) and Article 4(4) RED.
} 
targets for Member States. ${ }^{3}$ The European Parliament has, however, urged for a prolongation of the system of national renewable energy targets. ${ }^{4}$ If the approach as proposed by the Commission became part of a substantially revised renewable energy directive, the decisionmaking in the renewable energy sector would obviously be largely influenced, at not only national, but also regional and local level: by no longer having to fulfill binding national targets, it is to be expected that less pressure will be put on national and regional decisionmakers promoting renewable energy.

In the meantime, the European Commission attempts to guide Member States on their national renewable energy policies, including the reform of renewable energy support schemes. ${ }^{5}$ It is the wish of the Commission that national governments abandon the feed-in tariffs, currently the dominant form of renewables support in the EU, and to move to other support instruments, such as quota obligations. ${ }^{6}$ It remains to be seen whether the European Commission will be successful, for instance in the promotion of adoption of EU legislation, since Member States have thus far been reluctant with regard to harmonization here. The European Commission nonetheless states that "where public intervention is defined at regional, national or local level, the Commission invites the competent authorities to ensure consistent approaches across the whole Union". ${ }^{2}$ While such statements seem rather vague, they appear to entail the idea that differentiation in incentive systems and regulation for renewable energy among regional governments is to be avoided by means of streamlining approaches across the EU. Hence, a trend appears, at least at EU level, calling for harmonized action across the EU, both in terms of support mechanisms and of authorization procedures (as has been indicated in Chapters 2 and 7 of this book). Further harmonization of renewable energy legislation may lead to a less differentiated and, consequently less complex framework, but might also result in allowing less discretion for regional governments. The starting point for this book is the idea that local action will play an important role in the transition towards a low carbon society. It has to be explored to what extent room should be

\footnotetext{
${ }^{3}$ EU- Commission, A policy framework for climate and energy in the period from 2020 to $2030, \mathrm{COM}(2014) 15$ final of 22.1.2014, p. 6.

${ }^{4}$ European Parliament, MEPs want binding 2030 goals for $\mathrm{CO}_{2}$ emissions, renewables and energy efficiency, Press release Energy/Environment, Reference 20140203IPR34510, 5 February 2014.

${ }^{5}$ European Commission, Guidance for state intervention in electricity, Press release Brussels, IP/13/1021 5 November 2013.

${ }^{6}$ European Commission, Communication from the Commission, Delivering the internal electricity market and making the most of public intervention, C(2013) 7243 final of 5.11.2013, p. 15.

${ }^{7}$ European Commission, Communication from the Commission, Delivering the internal electricity market and making the most of public intervention, C(2013) 7243 final of 5.11.2013, p. 2, see also p. 8: "The Union law acquis may offer a European alternative to national or local public intervention."
} 
given to regional governments to make new policies stimulating renewable energy. Whether, compared to a patchwork of differentiated approaches, harmonization will eventually be more productive, has yet to be further considered.

In comparison, in the U.S., in the absence of a national energy policy, state governments play a leading role in the transition to renewable energy as discussed by Sanford Gaines in Chapter 13. Although most states have opted for quotas over feed-in-tariffs, individual states select their own priorities in the move to renewable energy generation, which results in a collage of targets and instruments. This means that one must look for patterns or trends among many states in order to gain an overall insight into U.S. renewable energy law. This is also a characteristic of current EU renewable energy practice, since the support measures are not harmonized and the attempt to harmonize administrative procedures in Article 13 RED is based on quite general terminology. It is not an easy matter to get an in depth view on how in the EU (and in the U.S.) renewable energy policies develop. This is a conseqence of the polycentric approach that characterizes renewable energy law, and climate law in general. $^{8}$

\subsection{National Policy Development and Regional Governments}

The main difference between the EU and the U.S. is that, while the U.S. has no binding federal targets, in the EU, binding renewable energy targets have been imposed on Member States, which basically means that national governments carry the responsibility. In order to reach these binding targets, adequate policies must be adopted by Member States following their National Renewable Energy Action Plans. Such approaches can consist of support measures in favour of private operators, which can lead to regional governments being given a strong push from the private sector to establish renewable energy projects. In this sense, regional government participation in developing national renewable energy policies and exploring the consequences for regional territories of such national measures deserves attention. Henning Thomas argues in Chapter 5 that the national feed-in-tariff approach as well as the obligatory direct marketing of electricity from renewable energies in Germany does not take into account the concern of regional governments. Gabriel Michanek shows in Chapter 8 that there is danger of a misbalance if, on the one hand, national targets have been established while, on the other hand, the legal framework, particularly a municipal veto

\footnotetext{
${ }^{8}$ See about polycentrism and climate law Cole (2011).
} 
opportunity, forms a barrier to achieving that target. These examples show that there is a need to strive for coherency in the national renewable energy policies, thereby taking account of the stakes and concerns of regional governments. The Committee of the Regions has already stressed this point in its advice for the proposal of the Renewable Energy Directive (see Peeters and Schomerus in Chapter 2). The Renewable Energy Directive stipulates in Article 4 that, in their National Renewable Energy Action Plans, Member States must describe which appropriate measures will be taken to achieve these national overall targets. It does, however, not require regional governments to be involved in the plan-development; the Directive merely prescribes the cooperation between local, regional and national authorities for achieving national overall targets. As far as it is known to the authors, no empirical data is available regarding the question of how, across the EU, regional governments have been involved in the national renewable energy action plan development, nor of how Member States wish to use their regional governments' capacity for implementing national targets. While, on the one hand, top down standard setting, like fast procedures and support measures, may be fruitful in view of reaching overall EU energy targets by 2020, problems might occur in the implementation phase during which local governments and citizens might resist the establishment of renewable energy in their territories.

Practice shows that the development of a coherent national policy may be a cumbersome matter: in Chapter 9, Stefano Fanetti and Barbara Pozzo describe how in Italy, after 25 years of work, it was not until 2013 that a new National Energy Strategy (Strategia Energetica Nazionale (SEN)) was published, the first organic strategic document in the Italian energy sector. This national policy identified, inter alia, ways to improve coordination between state and regions in legislative functions, and between the state, regions and local authorities, in administrative functions. From Chapter 4 which deals with the Spanish situation written by Iñigo del Guayo, it becomes clear that coordination with other plans is also necessary, although such coordination may take place at sub-national level. For instance, the Councillor in Andalusia responsible for energy must design a programme for the development of renewable energy sources, taking the territorial, environmental, cultural, urban and infrastructural conditions established in other plans into account. This requires conducting a comprehensive consideration of various and different plans.

\subsection{Competence Structure, Constitutional Setting}

Concerning the structure of competencies in the Member States and their constitutional settings, the overarching question is whether, with regard to fulfilling the renewable energy 
targets, a high level of regional and local autonomy is favourable. It could, however, be argued that strict requirements at EU and/or national level with only little leeway for regional and local decision-making would lead to a more effective and efficient implementation of renewable energy targets.

A look at the relationship between the EU and its Member States does not give a clear answer to this question. On the one hand, it shows a possible future shift towards more freedom for EU Member States in the renewable energy sector. By not setting new binding targets for 2030, the EU-Commission proposes giving Member States - and, in consequence, the regions - increased flexibility. On the other hand, according to the Commission, "different national support schemes need to be rationalized to become more coherent with the internal market, more cost-effective and provide greater legal certainty for investors". 9 An EU-wide harmonization would lead to less flexibility for Member States in choosing their individual modes of national renewable energy support schemes, and, consequently, it would also lead to less discretion for regional and local level decision-making.

Regarding the allocation of competencies between national and regional level, the example of the U.S. shows that although a complete absence of a coherent national energy policy may not be the ideal pattern for the promotion of renewable energies, it has not been an obstacle to rapid growth in both wind and solar power production. In Chapter 13, Sanford Gaines emphasizes the leading role of state governments in assuring energy supply and regulating energy prices, especially for electricity. While some states have successful promotion schemes and programmes, others are less ambitious in promoting renewable energy. Gaines highlights the prominent role of "community" energy in the U.S. with its bottom-up approaches, which is actively promoted by local and state legislation in many states. Community energy, by engaging local landowners and governments in decision making and in the economic benefits of energy development, by its nature avoids the "not-inmy-backyard" attitudes which block renewable energy development. But big commercial projects still dominate the U.S. renewable energy market, making clear that "community" energy and low-level decision-making alone are a long way from being sufficient drivers for increasing national renewable energy supply.

On the contrary, as Henning Thomas shows in Chapter 5 on the German system of feed-in tariffs guaranteed for 20 years, clear, supportive and applicable regulations are needed at national level. The German Renewable Energies Act $(E E G)$ provided valuable support for

\footnotetext{
${ }^{9}$ EU- Commission, A policy framework for climate and energy in the period from 2020 to 2030, COM(2014) 15 final of 22.1.2014, p. 7 .
} 
regional and local wind-farms, photovoltaic installations, biomass plants, and so on. A strong national and sub-national promotion scheme facilitates bottom-up approaches such as local community investment in renewable energy projects described by Lars Holstenkamp in Chapter 12. This means that fulfilling renewable energy targets needs both, a strong and longterm reliable supra-national and national promotion scheme, as well as bottom-up approaches such as "community" energy. However, the EEG which came into force 1 August 2014 and the upcoming auctioning procedure for new renewable energy installations make regional and local investments a much more risky business.

In Chapter 4, Iñigo del Guayo states that decentralization, through the creation of 17 autonomous communities, has been beneficial for the promotion of renewable energies in Spain. Regional governments, in an attempt to satisfy increasing social awareness towards climate change, have competed among themselves for the greatest installed renewable capacity. This "competitive federalism" could also, however, lead to a "race to the bottom". As in other areas with public intervention, the major reason for the Spanish "race to the top" was the high level of remuneration for renewable energy fixed by the national government. In line with the stressed Spanish state's financial situation which led to the reduction to a minimum of support for renewable energy, there will probably also be less future competition between the autonomous communities to increase renewable energy usage.

A comparable development can be seen in Germany, a Member State with a federal system giving its Länder a large share of power in legislation and administration. Similar to the U.S.A., but different from the constitutional situation in Spain, the German Länder are considered states in their own right. As Henning Thomas mentions in Chapter 5, the state of Schleswig-Holstein, for instance, expressed the wish to generate 300 per cent of the state's electricity consumption through renewable energies. Other states also pursue their own political objectives with regard to renewable energy. This leads to a conflict between the federal state and the Länder. According to the Basic Law, the federal state has the legislative competency for making the rules for financial support, in particular for defining feed-in tariffs and further requirements. The Länder, however, play an important role in the legislative procedure through their representation, the Federal Council. Moreover, they enjoy the exclusive competency for spatial planning and the administrative authorization, certification and licensing procedures for renewable energy plants. Apart from determining the financial support provisions, the federal state cannot, for example, order the Länder administrations to either stay within a certain number of renewable energy plants licensed by their authorities, or to not exceed a certain amount of electricity produced within their territory. Again, this 
example shows that both sides, the federal state as well as the regions, must work together responsibly to implement the EU's and Member States renewable energy targets.

It is worth comparing the German federal system with the same legal status of all 16 Länder, and the "imperfect federation" of Spain, in which autonomous communities have limited power in federal legislation. Even autonomous communities such as Catalonia, Andalusia or Galicia, enjoying a higher level of autonomy than other regions, have limited constitutional ways to take part in the federal law-making procedure; there are prospects for the Senate to be transformed into a true representative of autonomous communities. It would seem that the German system, with the strong legislative position of the Länder and their aspiration to improve their regional economy, is more suitable in terms of a reliable and constant promotion of renewable energies.

Moreover, in terms of competences, of great importance for the development of renewable energy is the constitutional role of municipalities. Conflicts may, on the one hand, arise between state and local levels, or, on the other hand, between regional and local levels. In Chapter 8, Gabriel Michanek writes about the Swedish conflict between the national wind power objective and the 290 self-governing municipalities, pointing out that municipal competencies for local planning, even including a municipal veto-right, create a barrier for implementing national renewable energy targets.

In Sweden, and in some other EU Member States, municipalities enjoy a high level of autonomy. In Germany, for instance, according to Article 28 par. 2 Basic Law, municipalities must be guaranteed the right to regulate all local affairs on their own responsibility. As Christian Maly points out in Chapter 11, conflicts of competence can arise between the Länder responsible for spatial planning and the municipalities with their constitutional right to draw up local land-use plans. The Länder often set themselves ambitious renewable energy targets. However, they have no competency to impose preconditions on the municipalities, for example, in the form of local quotas. Municipalities often reject the ambitious Länder-targets, in their representation of local citizens not wanting wind-farms or biomass plants (NIMBYeffect). Such conflicts are often dealt with at the administration courts, in particular the Federal Administration Court.

There is no general rule for high level regional and local autonomy automatically leading to greater support for renewable energy. Competence structure and constitutional settings differ considerably between the various states. An interesting example of the diversity between the Member States is given by Stefano Fanetti and Barbara Pozzo in Chapter 9. They describe the progress of re-centralization in Italy through harmonizing national and regional 
legislation. As a result of this process, not only the authorization process would be made uniform but also national interests would prevail over local concerns. According to the authors, in the case of Italy, the highly autonomous local and regional status hampers the development of renewable energy.

This leads to the observation that a combination is needed of (1) ambitious objectives set out in binding requirements for the promotion of renewable energy at state level, as well as (2) bottom-up approaches with citizens' initiatives, backed by regional and municipal support at regional and local level. However, the design of a sound legal framework for renewable energy in the EU cannot be seen apart from the other instruments introduced for climate protection, particularly the EU emissions trading scheme (ETS), established by Directive 2003/87. The EU-wide approach, with an EU-wide cap and a common market price for tradable greenhouse gas allowances, has a potential impact on the competition between fossil fuel energy and other sources of energy, including renewable energy. Hence, the need for national, binding renewable energy targets has to be considered in the light of efforts to strengthen the EU ETS. ${ }^{10}$

\section{Finance}

With regard to the costs of generating electricity, to date, several forms of renewable energies still struggle to compete with fossil and nuclear sources. ${ }^{11}$ While renewable energy installations require high financial investments, operational costs are relatively low. ${ }^{12}$ In the long run, renewable energies may therefore be the most cost efficient for electricity generation. However, for a given transitional period, financial support is needed for promoting technical innovation, making renewable energy more competitive, and for fulfilling the EU-targets. The crucial role of financing renewable energy has been emphasized in several chapters of this book. In the following, in Section 3.1, conclusions will be drawn

\footnotetext{
${ }^{10}$ Peeters (2014); Ekardt, Klinski and Schomerus (2014).

${ }^{11}$ A recent study done by Fraunhofer Institute for Solar Energy System (2013), p. 2, for instance shows that "wind power at very good onshore wind locations already has lower costs than new hard coal or CCGT power plants".

12 German Advisory Council on the Environment Sachverständigenrat für Umweltfragen (2013), Shaping the Electricity Market of the Future, Special Report, 2013,

www.umweltrat.de/SharedDocs/Downloads/EN/02_Special_Reports/2012_2016/2013_11_Sp ecial_Report_Electricity_Market_KfE.pdf?_blob=publicationFile, (accessed 27 August 2014), p. 55; see also Bundesministerium für Wirtschaft und Technologie (2013), Energie in Deutschland, Trends und Hintergründe zur Energieversorgung, Www.unibielefeld.de/chemie/arbeitsbereiche/pc2/download/energie-in-deutschland.pdf (accessed 27 August 2014), p. 37.
} 
for legal aspects of supporting and promoting renewable energy. In Section 3.2, we cast a glance at the financial participation of citizens in such projects.

\subsection{Legal Aspects of Supporting and Promoting Renewable Energy}

\subsubsection{Legal barriers to promoting locally produced renewable energy}

While it is the role of the law to provide a clear framework for guaranteeing renewable energy investments' feasibility, in many cases legal obstacles impede such promotion measures. As discussed by Hartmut Kahl in Chapter 3, one of these measures might be a policy of local authorities which pursue the generation of renewable electric energy regionally by favouring a local tenderer when procuring the energy, for example, for their public buildings. In such cases legal barriers can emerge from EU-procurement law according to which a policy favouring local tenderers turns impermissible as soon as a relevant threshold is reached. A very limited exception is made if the authority's control over the tenderer is similar to that over its own departments and the tenderer carries out the essential part of its activities with the authority. Also, renewable energy support schemes enshrining so-called local-content requirements have spread all over the world. Such provisions exist also in several EU Member States. They give privileges if the renewably produced electricity is generated in a power plant that is manufactured from domestic production, at least to a certain percentage. Legal barriers for such approaches can, for instance, derive from the law of the WTO as the first settled dispute case involving the local-content requirement in the feed-in tariff programme of the Canadian province Ontario has shown recently.

Lars Holstenkamp describes in Chapter 12 that local investment schemes are a rising form of a bottom-up approach towards the financing of renewable energy installations. Often municipalities take part in such schemes, either as an initiator or, as Christian Maly points out in Chapter 11, as partners in an energy cooperative. Such municipal action could come into conflict with either public procurement law or WTO law. It could also violate state aid law as laid down in Article 107 TFEU. The required further exploration of this aspect goes beyond the scope of this book.

As Henning Thomas (Chapter 5) explains, using the German Renewable Energy Sources Act $(E E G)$ as an example, national law does not take into account the specific circumstances of regional governments. As federal law, the EEG neither considers the region where electricity is generated nor how installations are financed. There is, for instance, no 
"bonus" for wind-farms financed by local investment schemes. However, Henning Thomas points out that a future EEG could possibly "reward" a wind-farm location close to an appropriate grid or to relevant consumers by granting a higher feed-in tariff. By the same token, such bonus could be awarded to citizen-owned wind farms as described by Christian Maly in Chapter 11. This could also increase local acceptance and reduce the NIMBY-effect.

\subsubsection{Support measures}

Measures for supporting and promoting renewable energy are embedded in the complex energy market. Moritz Meister explains in Chapter 6 that, to date, dependent on the low price level for tradable greenhouse gas allowances, renewable energy cannot compete with electricity generated from fossil fuels such as lignite. Moreover, intermittent renewable energy sources such as wind and solar power must be complemented by new, highly flexible power plants, that is, gas and steam-turbine power plants, and storage facilities. The existing energy-only market does not offer sufficient compensation for the provision of electricity from such plants. This is the reason for discussing the option of a capacity market, enabling the recovery of fixed costs. In other words, energy markets are changing, and support measures for renewable energy are under constant pressure to make the necessary adaptations to their changing economic environment.

Capacity markets are not the only support measure discussed for increasing the renewable energy's share in the electricity market. A major, widespread instrument comes in the shape of guaranteed feed-in tariffs. As Henning Thomas writes in Chapter 5, the 2012 German Renewable Energy Sources Act (EEG) provides such guarantees for a period of 20 years, from the commissioning of the facility on. He also mentions the EEG-privilege awarded to certain energy-trading companies which are exempt from the so-called $E E G$ surcharge. This exemption enabled traders with at least 50 per cent electricity from renewable sources in their portfolio to reduce prices for their customers. However, due to relatively rigid conditions under which this so-called green-trader-privilege is awarded, it currently only plays an unimportant role. In the new EEG, which came into force on 1 August 2014, the green-trader privilege could have become a more relevant support measure. However, renewable energy projects could be financially supported by a reduction of the EEGsurcharge, if the energy is not only produced through renewables but also consumed locally. Local customers would then gain profit from reduced energy prices. From the perspective of local acceptance of renewable energy generation, it is a pity that the German government did 
not consider this instrument as part of the plan to fundamentally revise the EEG. On the contrary, , the green-trader privilege has been deleted entirely. ${ }^{13}$

Since the $E E G$ is federal law, not regarding such local and regional interests as highly important may seem understandable. Nevertheless, this raises the question whether local and regional concerns are sufficiently taken into account in supra-regional decision-making on national or on EU-level. We have pointed at the Committee of the Regions (CoR) as the representation of the regions at EU-level. In Chapter 2, we mention that the CoR has given advice with regard to the Commission's proposal for the RED. There are, however, no clear findings as to whether this influenced the legislative institutions' opinions. Thus far, the CoR has not made use of its right, given by the Lisbon Treaty, to address the Court in order to protect its prerogatives (Article 263 TFEU). The value of this new judicial right of the CoR has yet to be further explored. As long as the CoR lacks real power - one can even think of a veto right, which obviously would be a very far going influence - the voice of the regions might remain neglected in the legislative process. At the same time, giving more power to the CoR will also put more attention to the legitimacy of its functioning and the quality of its decision-making.

We have seen that support measures are mainly created and put into force at national level. This can be shown clearly by the Spanish example described by Iñigo del Guayo in Chapter 4, according to which key competences are given to the central government, while competences of the autonomous communities are basically limited to authorizing generation units of less than $50 \mathrm{MW}$ installed capacity. Autonomous communities are permitted to plan numerous new renewable energy installations, although they may not exceed the targets set by the nationwide plan. (Financial) support measures at regional or local level therefore play only a subordinate role.

Another support measure on local level is being implemented in Germany where, as Christian Maly mentions in Chapter 11, the municipality in which a wind farm is located receives 70 per cent of the local business tax - calculated on the basis of the wind farm's revenue.

There is as yet no EU-wide overview on how support systems promote communitybased arrangements. Article 14 RED requires Member States to provide several kinds of information, for instance to ensure that information on support measures is made available to

\footnotetext{
${ }^{13}$ See Bundesregierung (2014), Eckpunkte für die Reform des EEG, www.bundesregierung.de/Content/DE/Artikel/2014/01/2014-01-22-eckpunkte-eegreform.html;jsessionid=39CA12D22CCAE51B3F42ADD44C9B06D1.s1t1 (accessed 27 August 2014), p. 9.
} 
all relevant actors (Article 14 para. 1 RED). According to Article 14 para. 6 RED, Member States, with the participation of local and regional authorities, shall, inter alia, develop suitable information in order to inform citizens of the benefits and practicalities of developing and using energy from renewable sources. Article 22 RED requires the Member States to submit reports to the Commission on progress in the promotion and use of energy from renewable sources. This, however, does not include reports on support systems for community energy.

A different situation from that of the EU can be seen in the U.S.A. Although, as Sanford Gaines writes in Chapter 13, in the U.S.A., "community" energy is important, financing renewable energy projects still depends heavily on federal investment (solar) or production (wind) tax credits. However, tax credits only give profit to taxpayers but not to local governments or non-profit organizations. As Gaines mentions, there are some complementary incentive measures for these non-taxpaying entities. In Oregon, for example, local communities, tribal governments, schools and so on can obtain feasibility study grants for renewable energy investments. The state of Minnesota gives tax privileges to solar and wind-related personal property. Other federal programs help support projects undertaken by electric cooperatives or in rural areas. Finally, creative financing arrangements enable initial project financing by outside passive investors who benefit from the tax credits, with the completed projects returned to full local ownership and operational control.

Again, as already said above in Section 2.3, a wise cooperation among central and regional governments is urgently needed. Support measures should be set up on national, that is, federal or state level, but should not block regional and local incentives for renewable energy initiatives.

\subsubsection{Financing virtual power plants}

By installing so-called virtual power plants, renewable energy can play a more important role in the energy market. A virtual power plant clusters separate electricity generation installations, for example wind farms, hydro power and biomass plants, solar parks and storage facilities. They are operated by a central control unit, guaranteeing that a certain amount of electricity is fed into the grid at a certain time. By using this instrument, the problem of intermittent generation from renewable energy sources, such as wind and solar power, can be reduced. Virtual power plants can thus offer electricity to the market as one entity. The feasibility of a regional virtual power plant which also integrates smart-grid and 
demand-side-management tools is currently being analyzed in the Energion-project at the German Leuphana University in Lüneburg. ${ }^{14}$ This could help to make a region energyautonomous and reduce dependency on extra-regional energy supplies.

However, as Moritz Meister points out in Chapter 6, financing the implementation of a (regional) virtual power plant is a key challenge for the economic and legal framework. Capacity markets, as described above in Section 3.1.2, could improve the feasibility of such power plants. In Germany, capacity fees are currently only awarded within control reserve markets. Installing virtual power plants which are, at least partly financed through the reserve control market, should therefore be taken into consideration by regions and municipalities as a support of renewable energy at regional and local level.

\subsection{Local Investment Schemes}

\subsubsection{Putting financial participation on the agenda}

The opportunity for citizens to participate financially in renewable energy activities is an emerging and interesting topic, to which a range of legal and economic aspects are attached. In the field of environmental law, the establishment of commercial activities not only affecting the environment but also citizens' interests is a well-known phenomenon. Traditionally, such conflicts are solved by respecting the right to enjoy private and family life (Article 8 European Convention on Human Rights (ECHR)) and by the right to enjoy property as protected by Article 1, First Protocol of the ECHR. One example is the Fägerskiöld v Sweden "renewable energy case" brought to the European Court on Human Rights. The applicants, inter alia, complained, under Article 8 of the Convention and Article 1 of the First Protocol to the Convention, that the continuous, pulsating noise emanating from the wind turbine and the light reflections from its rotor blades interfered with the peaceful enjoyment of their property, making it impossible to enjoy their private and family life. ${ }^{15}$ The Court rejected the claims, referring to the wide discretion resting with the government, but also to the fact that the applicants had failed to exhaust all domestic remedies available, "as they failed to institute any proceedings at the national level for financial compensation for the alleged loss of value of the property". ${ }^{16}$ This illustrates the importance of national law for the protection of

\footnotetext{
${ }^{14}$ See the website at www.leuphana.de/en/partners/innovation-incubator-lueneburg/sustainableenergy/energion.html (accessed 27 August 2014).

15 Fägerskiöld v Sweden, 26-02-2008 (Third Section) application number 37664/04; see furthermore Ellen Desmet (2010), p. 314.

${ }^{16}$ See p. 19 of the court decision mentioned in the previous footnote.
} 
citizen's rights. As far as is known to the authors, EU environmental law has not yet established financial provisions such as financial compensation obligations in case a commercial activity produces "environmental nuisance" to citizens. ${ }^{17}$

Chapter 2 questions the scope of Article 13 RED as it sets requirements, albeit vaguely, for the authorization of renewable energy projects. This Article demands that "any national rules" concerning the authorization be proportionate and necessary. A broad interpretation of "any national rules" also includes national civil law procedures, although it is unlikely to have been the legislator's intention. However, as soon as administrative law provides rules relating to financial compensation or participation regarding citizens, these rules may have to comply with the requirements of Article 13 RED. Particularly in the field of renewable energy, the discussion has emerged concerning how to involve citizens or local communities in the commercial operation of renewable energy. As Birgitte Egelund Olsen explains in Chapter 10, it must be assumed that offering citizens financial involvement in renewable energy generation, as through local ownership or a compensation provision, might have a positive effect on local attitudes to wind farms. Regarding the latter, the Danish Renewable Energy Act of 2001 gives property owners a right to full compensation for the loss of value of their property after wind turbines are sited in their vicinity. Egelund Olsen points out the important difference between, on the one hand, the local citizens' financial involvement and on the other hand, financial compensation. The latter redresses the economic injustice incurred when the common good is served by inflicting some form of a renewable energy facility on a neighbourhood. Egelund Olsen argues that this redress of economic injustice needs to be approached cautiously and as early as possible in the process. It could otherwise even be perceived by a local community as a bribery attempt.

Since there is as yet no EU guidance or policy development on either financial citizen participation or financial compensation, it is interesting to see that, bottom up, some experimentation is taking place with a wide variety of citizen or community financial participation in renewable energy generation. This could even have an impact on environmental law approaches to other activities, such as the establishment of industries. Why should financial citizen- or community-involvement only be an option in the case of renewable energy but not for other activities affecting local citizens? First, however, a deeper understanding of the different design options and the related legal and economic issues must

\footnotetext{
17 The Environmental Liability Directive only covers environmental damage, and excludes cases of personal injury, damage to private property or to any economic loss, Directive 2004/35/EC, preamble 14 . The question how in view of EU competences there is a possibility for EU action in order to regulate financial payments to citizens in order to compensate for environmental hindrance falls outside this chapter.
} 
be gained. The emerging practice regarding financial citizen participation to renewable energy generation provides a useful opportunity for further learning.

\subsubsection{Terminology and typology}

Most environmental and administrative lawyers associate the term "participation" or "citizen participation" with procedural provisions enabling citizens to participate in governmental decision-making, for example, a procedure for an environmental permit for a biomass installation. In this book, several chapters deal with financial citizen participation. This refers to citizens being involved financially in the business of renewable energy production. In this respect, in Chapter 10 Birgitte Egelund Olsen distinguishes two types of citizen ownership:

[bl] - First, proactive citizen ownership: this involves incentives to invest in renewable energy developments before the final authorization has been made according to public law. For example, the Danish Renewable Energy Act established a Guarantee Fund to support preliminary investigations by local groups with regard to realizing wind energy projects.

- Secondly, reactive citizen ownership: this relates to ownership initiated after the renewable energy project has obtained its final authorization according to public law. For example, the Danish Renewable Energy Act imposes an obligation on all new wind energy developers to offer a minimum of 20 per cent ownership of a project to local citizens.[/list]

The idea behind local ownership is the promotion of local acceptance, since local developers are assumed to be better embedded in the local community, to have better knowledge of local conditions and thus, greater credibility and are in a better position to mobilize support and acceptance. In Germany, the phenomenon of citizen-owned wind parks has emerged, the socalled Bürgerwindparks. These are wind farms owned by local residents of the municipality in which the wind turbines are located. Christian Maly discusses the legal form of such citizen wind parks, and points at the lack of a law or regulation defining a special ownership structure for citizen wind farms.

Other than citizen involvement, regional governments may also become involved in a renewable energy business, as explained by Lars Holstenkamp in Chapter 12 and Christian Maly in Chapter 11. In this case, a wind park could be owned by a municipality. However, as Maly shows, according to German law a municipality is not permitted to establish a company 
with the sole intention of profit realization. This creates an obvious barrier to local wind park ownership, at least to ownership by a municipality. Other models, such as contracts between municipalities and land-owners may not be in conformity with public law. If no legal clarity is provided, the financial participation of municipalities in wind energy parks is most unlikely to be high; moreover, the fundamental question remains whether such financial participation by municipalities should be promoted as an alternative to citizen participation.

In Chapter 13, Sanford Gaines takes a broader perspective with community renewable energy in the U.S. as a starting point, thereby discussing a rich range of different constructs that have emerged in practice. Such community owners or investors can be individuals, small businesses, local or tribal governments, municipal utilities or electric cooperatives. Both citizens and governments may be part of a community renewable energy project, but practice shows that most community wind or solar projects are initiated by individuals and small businesses, who are then the owners or the potential financial beneficiaries of a communitybased project even if they rely on outside investors to finance construction costs. For delineating community participation, a flexible definition is applied in terms of project scale, from the very small to a large project with a capacity of $150 \mathrm{MW}$. All cases discussed by Gaines are characterized by financial community participation and a community financial stake.

From an economic/financial perspective, Lars Holstenkamp in Chapter 12 presents an overview of different financial investment schemes, thereby distinguishing between local investment schemes in a proper sense (or "community ownership schemes"), and local investment schemes in a broader sense (or "mere financial participation"). Real participation from a financial and legal, but also from a political perspective only occurs where citizens can exercise a certain amount of control. Legally and financially, this is the case where citizens invest in the company or the project. As Holstenkamp shows, this can refer to a variety of different legal forms. Citizen participation, or local investment, either comes in the form of mere financial participation with only insignificant decision rights, or is bound to shares in the issuing firm. The greater the decision-making power involved in participation, the higher the risks.

In his chapter, Lars Holstenkamp provides a rich illustration of the many different legal forms that can be used for both forms of financial participation, and he points at the fact that, to date, neither an inclusive database exists for legal forms for citizen participation schemes in Germany, nor a comparative database covering financial participation schemes in EU Member States. Given the many different views on terminology and typology, it is 
understandable that creating databases is a difficult undertaking. Holstenkamp for instance points at the fact that a municipal utility per se is seen by some experts as an (indirect) citizen participation - perhaps a more just citizen participation, since every member of the respective community is represented in the utility through the council and the utility's board.

\subsubsection{Experimentation and experiences with financial participation}

It is still too early for concluding observations or recommendations on financial participation schemes for citizens. Despite this fact, several authors have drawn attention to interesting preliminary findings.

Holstenkamp points at the following paradox: Financial participation is seen as an instrument to increase acceptance of renewable energy projects. The level of participation in decision-making depends on the form of investment used. It is high in the case of equity capital given by community members. At the same time, this is the riskiest type of investment. Equity capital with its high risks is not a suitable type of investment for all people - something to be considered also from the perspective of investor protection laws. At the end, there is some kind of participation-risk trade-off, and further research is needed in order to understand what form of financial participation can be preferred.

Birgitte Egelund Olsen describes several experiences with citizen participation and compensation schemes in Denmark. Generally, experience with Danish wind energy projects reveals that complaints are made more often if wind turbines are installed by external investors or large energy companies, than by members of the local community. She also explains that often there is less opposition if a large number of locals take advantage of the co-ownership option. This must not be regarded as simply as it sounds, since from a local community perspective these schemes havenot always been a success. Egelund Olsen points at the appearance of so-called "wind energy nomads", investors buying up adjacent properties to become neighbours and thus eligible to take part in the co-ownership scheme, but terminating their residence as soon as their aim is accomplished. This example demonstrates how, as soon financial profits are gained, a secure legal framework must be established if abuse and perverse effects are to be avoided. From another angle, the design and scope of the financial provisions deserve attention: regarding the financial compensation scheme, Egelund Olsen discusses the difficulty citizens have in comprehending that the nuisance caused by wind turbines is not compensated but rather the impact the wind turbines have on property values. If a property has little value, the owner may not be eligible for compensation even 
though a wind turbine is located very close to it and causes noise and shadow flicker problems.

In addition to these important Danish experiences, Birgitte Egelund Olsen points at some uncertainty in EU law regarding the legality, under the co-ownership scheme, of requiring a potential wind turbine investor to be a local resident. This restriction on the free movement of capital could violate Article 63 TFEU. Whether or not innovative constructions aiming to promote financial citizen participation are in conformity with EU and national law must be explored. For example, Christian Maly points at obstacles in German law for financial municipality schemes, that is, not being able to adopt a binding land-use plan which allows only wind farms with municipal financial participation.

\section{Authorizing renewable energy}

\subsection{The Role of Authorization}

\subsubsection{In search of best practices embedded in a coherent administrative law-scheme}

Regional governments' most important legal task for the transtition to a low carbon society is most likely executing public law competences for the authorization of renewable energy projects. As explained in Chapter 2, renewable energy activities, especially larger ones, require a string of authorizations before they can start. This concerns not only environmental law authorizations but also spatial and building authorizations. Public participation procedures must be applied in relation to these governmental permissions, particularly in the case of renewable energy projects that might have a significant effect on the environment, in which case Article 6 of the Aarhus Convention applies. As pointed out by Kars de Graaf and Albert Marseille in Chapter 7, the evaluation by Member States of the efficiency of authorization procedures for renewable electricity projects was required by the Renewable Energy Sources Directive (RES Directive) of 2001. Chapter 9 by Stefano Fanetti and Barbara Pozzo shows that, for a long time, despite such an evaluation effort, the regulatory framework for renewable energy in Italy could be characterized as chaotic and fragmented, a situation which contributed to competence conflicts between national and sub-national governments.

The Renewable Energy Directive from 2009 established new obligations for Member States concerning the authorization of renewable electricity and renewable heating and cooling. The basic idea from Article 13 of this Directive is that procedures should be necessary and proportional; Chapter 2 explains the relevance for a wide range of 
environmental and other authorizations that may be applicable for renewable energy projects. The requirements of Article 13 RED are rather vague, leaving Member States considerable discretion. The best way for Member States to implement this Article has yet to be clarified. In its Renewable Energy Progress Report from 2013, the European Commission gives a critical assessment of Member States' practice, even threatening with infringement action. ${ }^{18}$ What exactly can be enforced through Article 13 remains questionable. Fundamental questions yet to be answered are (1) what could best practices be regarding the design and application of authorization procedures; and (2) to what extent should they be prescribed by EU secondary law? Furthermore, the question of efficient procedures is not unique to renewable energy activities: While preserving environmental values and public participation rights, unnecessary and disproportionate requirements should not be made for other business activities either. Given the emphasis in EU law on the efficiency of renewable energy procedures, the coherence of administrative law might be endangered if a focus is laid on efficient procedures for renewable energy activities only. Attempts to make procedures more efficient should take place in the wider context of improving administrative law procedures. By harmonizing procedures for renewable energy activities with other administrative law procedures, Member States could implement Article 13 more coherently. It remains to be seen whether "special" provisions for renewable energy projects would still be needed.

\subsubsection{Small impacts should not be ignored}

As Sanford Gaines observes in Chapter 13, most community renewable energy projects are relatively small and do not have serious environmental impact. Particularly in densely populated areas such as many in Europe, some nuisance may nonetheless occur, such as shadow effects of small windturbines, the flickering of sunlight from windturbines or photovoltoaic panels or the cutting of a tree to allow the sun to shine on the roof. Dealing with low-level impacts lies normally in the hands of the lowest authorities. Even small impacts deserve mapping. Attention must be given to investigating impacts to third parties and/or the environment caused by establishing and operating renewable energy projects, as well as any barriers to small renewable energy projects and their removal. This might be the situation where a citizen or small community such as a school wishes to establish photovoltaic energy generation and an adjacent garden or a planned adjacent building causes too much shadow for this to be profitable. The question emerges whether building codes or civil law are sufficient

\footnotetext{
${ }^{18}$ European Commission, Renewable Energy Progress Report, Brussels, 27.3.2013 COM(2013) 175 final, p. 8.
} 
to deal with such conflicts of interest. A good understanding of (even small) impacts caused by community and individual citizen projects, and an assessment of how to deal with conflicts of interest ultimately supports the transition to renewable energy. To the best of our knowledge, no thorough comparative research has yet been conducted, investigating legal frameworks and related best practices across the European Union, mapping the emerging problems between neighbours and municipalities, or exploring which municipal, regional, national (or even European) rules apply or should be established.

\subsubsection{Distribution of competences}

For large renewable energy projects, competences often lie with authorities higher in rank than municipalities, for dealing with environmental impacts. The chapters discussing the situation in Italy and The Netherlands show some shifts of competences to higher governmental level. Stefano Fanetti and Barbara Pozzo clearly explain that legal uncertainty regarding the distribution of competences in Italy has contributed to the slow development of renewable energy projects. Without a proper and clear framework, legal conflicts, even constitutional conflicts may emerge (depending on the law and particularly the constitution of the nation state), especially when lower authorities resist renewable energy activities. Renewable energy projects have given rise to a conflict between, on the one hand, the need to protect global concerns such as fighting climate change and, on the other hand, the possible emergence of negative local and environmental impacts. Municipalities are more likely to prevent negative local impacts than contribute to the global effort to lower greenhouse gas emissions. Resistance can grow against the establishment of a new economic activity, in the form of renewable energy, if the economic profits go to an energy operator, perhaps a large multinational energy company with no real connection to the local society, thereby causing negative effects for the community. Regarding the distribution of competences for renewable energy activities such as wind energy parks, the concerns of the community in which the impacts of the project will be felt need to be considered. Local resistance may take place, particularly if the responsibility shifts to higher governmental levels, unless community concerns are considered. The situation in The Netherlands as discussed by Kars de Graaf and Albert Marseille seems to be falling short in this respect, since much emphasis has been placed on expediting procedures and shifting powers to the higher governmental level, particularly in the case of large renewable energy projects. Follow-up research is needed to clarify how community concerns can be sufficiently considered, despite the shift of 
competences to a higher level. As discussed in Section 3.2 of this chapter, financial participation mechanisms may be part of the solution.

\subsection{Public Participation}

Member States must draw up their authorization procedures for renewable energy activities in accordance with the Renewable Energy Directive. As expressed in the Renewable Energy Progress Report published in 2013, the European Commission is unsatisfied with national practice. ${ }^{19}$ However, the European Commission appears to overlook the role of public participation in these authorization procedures, which is followed by access to the court for a limited number of persons having participated in the decision-making process. International law, particularly the Aarhus Convention, requires such public participation and access to the court if a project has significant effect on the environment; this right exists for the "public concerned" including environmental organizations. ${ }^{20}$ Birgitte Egelund Olsen stresses in Chapter 10 the need for more open and transparent decisions, taking into account the diversity of stakeholders involved or affected by proposed renewable energy projects. She warns of the risk that opposition or conflict between stakeholders will intensify if local concerns are brushed aside or insufficiently considered. This could also weaken general support for renewable energy projects. Stefano Fanetti and Barbara Pozzo stress that public participation needs to be part of the transition to renewable energy, as part of a broader package containing proper information disclosure and compensation provisions. In some Italian regions, like Tuscany, experimentation is taking place with new models based on a French participation scheme. It is our opinion that the European Commission should consider more thoroughly how, also using new models, adequate procedures can be provided with regard to public participation, thereby considering the importance of local support. As already emphasized in the previous section, regional governments may have a tendency to protect their citizens' concerns - like living conditions or property value - rather than contributing to solving the global problem of climate change.

It is also insufficient to focus merely on administrative decision-making procedures without considering the efficiency of court procedures. Article 13 only refers to the first, but if, after an adequate administrative decision-making process a cumbersome and lengthy court procedure followed, the main aim of starting up renewable energy projects would be hindered.

\footnotetext{
${ }^{19}$ See the previous footnote.

${ }^{20}$ See more precisely Article 2(5), Article 6 and Article 9(2) Aarhus Convention on access to information, public participation in decision-making and access to justice in environmental matters.
} 
Kars de Graaf and Albert Marseille highlight some Dutch legislative efforts to make court procedures more efficient in view of promoting economic activities (Chapter 7). They show that in a country like The Netherlands the public influence on authorizations has diminished after the introduction of the so-called relativity-related requirement in court procedures. This means that, especially in appeal procedures involving a large number of interested parties, the courts should not annul a decision by accepting grounds of appeal bearing no relation to the interests of the appellant. This requirement prevents citizens addressing environmental values for which no personal interest can be proven. Although it has been criticized in the light of the Aarhus Convention and its implementation in EU law, administrative courts have thus far argued that introducing the requirement is not in breach of any national or international provision. In other words, we can see that even without an EU provision national efforts take place, at least in The Netherlands, to expedite court procedures partly at the expense of public influence. Whether these legislative efforts can be qualified as best practices needs to be answered in further in-depth research.

How public participation could contribute to local support for renewable energy generation remains as yet an open question: it is not out of the question that wide public participation may even culminate in forming a barrier to renewable energy authorizations, since citizens eager to fight against renewable energy projects (because of nuisance or other concerns) may try to use such procedural provisions to the widest extent possible. We expect that public participation procedures in renewable energy projects may not be supportive to the renewable energy transition if no efforts have been made to gain local support for the renewable energy activities. In conclusion, the provision of public participation is internationally required, at least for renewable energy projects that may have a significant effect on the environment, although some room for discretion exists regarding both the specific design of public participation rights and access to the courts. For smaller projects not covered by the Aarhus Convention, public involvement still needs to be considered. Many, including several authors in this book, regard public participation as a necessity for local support, while realizing at the same time that such participation opportunities may be insufficient if no additional means are provided, such as proper information, compensation for damages and financial participation.

\subsection{NIMBY, ENGO's, and NIMTOO}


Clearly, regional governments must deal with the Not In My Backyard Effect: NIMBY. Section 3.2 discusses the development of financial participation approaches that might prevent citizen resistance to renewable energy projects. Apart from citizens' resistance, Environmental Non-Governmental Organizations (ENGOs) may use public participation opportunities in order to address regional government decision-making critically if renewable energy projects pose harm to environmental issues, that is, nature conservation, air quality or ecological aspects of water systems. Once authorities have established specific procedural or substantive provisions to overcome citizen (NIMBY) or ENGO resistance, such as the financial provisions applied in Denmark, their compliance with Article 13 RED must be analysed. The question is whether provisions intended to overcome citizen or environmental resistance are necessary and proportional. Taking into account the force of citizen and ENGO resistance, it can be argued that the establishment of extra provisions for overcoming such resistance is defendable as they promote the necessary development of renewable energy. Such procedures should, however, not become disproportionate and focus needs to be directed to the question of whether additional requirements for overcoming NIMBY and critical attitudes from ENGOs are really needed and proportional. This is particularly the case if such provisions, that is, financial requirements, are imposed on energy operators, who might claim that this is in contravention of Article 13 RED. They might also argue that such provisions impinge on the freedom to pursue an economic activity. Specific provisions intended to overcome citizen and environmental resistance ask for an exact design, allowing them to promote the establishment of renewable energy generation instead of placing an unnecessary burden on the energy operators.

The national legislator is given wide discretion in establishing specific mechanisms for dealing with citizen and environmental resistance. However, as is often the case with new laws established for new societal activities, in this case the transition to renewable energy, it is hard to predict which legal conflicts will emerge and how they will be dealt with by the courts. Case law can, on the one hand, concern claims from operators against provisions being part of an authorization process that they deem unnecessary or disproportional; on the other hand, claims may also be made by citizens and ENGOs demanding wider public participation or compensation provisions. In this respect, in Sweden, as Gabriel Michanek discusses in Chapter 8, not much room exists for citizens to submit substantive arguments against planning decisions. Persons with legal standing can appeal to municipal decisions regarding plans. This right to appeal is not an effective instrument, as the decision can only be subject to judicial review, without the option of questioning, for example, if the windturbine interest is favoured 
while neglecting other interests. Under current Swedish law, this balancing of interests is a matter for the municipality only. The Aarhus Convention refers to the fact that the public concerned must be enabled to address before the court the substantive legality of a decision that was subject to a public participation procedure. The exact meaning of this provision and its consequences for how (Swedish) courts must assess claims against environmental decisions has yet to crystallize. ${ }^{21}$

Stefano Fanetti and Barbara Pozzo introduced a phenomenon next to NIMBY and ENGO resistance - NIMTOO (Not In My Term of Office). While this phenomenon can also be applied to national politicians being reluctant to accept international emission reduction commitments that require great societal change in their term of office, it has been emphasized by Fanetti and Pozzo in view of the local politics in Italy. NIMTOO consists of an attitude of opposition, or at least in the aim to delay the establishment of a controversial infrastructure during one's own electoral mandate, without any assessment of the related public interest. The NIMTOO phenomenon in Italy needs to be understood in relation to citizens' protest against renewable energy generation, since local citizens' protest will encourage local politicians to take the side of their electorate and not follow the overall public interest in establishing renewable energy. In Italy, a NIMBY Observatory has been established, and it has indicated that in 2013 the electricity sector is the most affected by citizens' protests, with 213 works from a total of 336 being contested infrastructures, of which 153 concern renewable energy projects. This shows that the reform of Italian law, by strengthening and clarifying the competence distribution and simplifying the administrative authorizations (see below Section 4.4), has not prevented citizens' protest. According to Fanetti and Pozzo, the introduction of additional means to achieve a greater consensus is needed. First, they propose the provision of consistent and comprehensive information on renewable energy sources and a full implementation of Article 14 RED that contains information duties for Member States. Future research needs to show how, in several Member States, such information duties have been implemented, and whether such provisions contribute to the acceptance of renewable energy projects. Chapter 2 demonstrates that the Committee of the Regions has called for a full involvement of local and regional authorities in the development and implementation of information, awareness, guidance, education and training. The final provision of the Directive concerning information duties is however quite vague, again leaving much discretion to Member States. At the same time, it must be understood that the Aarhus Convention,

\footnotetext{
${ }^{21}$ Article 9(2) of the Aarhus Convention on access to information, public participation in decision-making and access to justice in environmental matters.
} 
implemented in the EU by, inter alia, Directive 2003/4/EC, provides citizens and ENGOs with an enforceable right to request environmental information, and in quite a few situations, renewable energy information may be covered by this right. Secondly, Fanetti and Pozzo stress the importance of (new forms of) citizens' participation in public decision-making, including the possibility of experimenting with new participation models. Thirdly, compensatory measures need to be considered in favour of the territories where the projects are located. The current Italian law stipulates that compensation measures must meet specific requirements: first of all they can be in favour of the municipalities, but not in favour of regions and provinces; they may not be monetary, purely economic, but they must be of an environmental and territorial nature; they are possible, concrete and realistic; finally, their value cannot exceed 3 per cent of the proceeds, inclusive of incentives in force, resulting from the value of electricity produced annually by the plant. While discussing and establishing compensation measures benefitting the local community where the renewable energy project is planned, attention must be paid to addressing the greed potentially present on the part of regional governments. As an example, we point to the fact that one regional government in Italy introduced a law, that, in clear contrast with the national rules, established automatic, monetary and exorbitant compensation measures, which must be paid half to the region and half to the municipalities concerned. After the appeal of the Government to the Constitutional Court, the region withdrew this law, which would most likely have been found illegal. This case shows how, sometimes, the regions are not interested in promoting renewable energy, but rather in obtaining an unlawful economic advantage, hindering de facto the development of these sources of energy.

\subsection{Towards Faster Procedures}

The idea of improving and streamlining authorization procedures for renewable energy projects can lead to coordinated administrative procedures and can ultimately culminate in the introduction of a one-stop governmental service desk for the approval of projects. Kars de Graaf and Albert Marseille show that the latter idea not only forms part of European Commission documents but has also been proposed in the European Parliament, although insufficient support was gained at EU legislative level to allow it to become a legal requirement. Coordination of administrative procedures (and the eventual one-stop procedure) may further the centralization of public authority and therefore diminish administrative competences and the influence of lower authorities. 
The chapter by Fanetti and Pozzo shows that at least in Italy, although a single authorization for renewable energy projects was already introduced in 2003, an amendment of the Constitution - converting the concurrent legislative competence between the State and the Regions in the field of energy into the exclusive competence of the State - might still be necessary to achieve the ultimate aim of a coherent procedural approach to renewable energy generation. The single authorization means that the permit application must be considered by the Regions (or by the delegated Provinces) through a single process, which implies the involvement of all administrative authorities concerned. This "conferenza di servizi" allows the simultaneous representation and analysis of all various public interests involved in the authorization process, which happens through a meeting of all authorities concerned. While this procedure initially seems to provide a fast and coordinated decision-making, the implementation has been troublesome. Clearly, the regions have used several means to hinder the development of renewable energy plants. This example shows that the establishment of a simplified procedure, even a single authorization procedure, is no guarantee for the fast development of renewable energy production: resistance at lower levels encourages authorities (and more likely, also citizens) to try to use all legal means that might hinder the establishment of renewable energy. Consequently, the Constitutional Court of Italy has had to resolve several conflicts between the national and regional governments. For instance, the court did not accept the provision introduced by the Region of Calabria, stating that the application for authorization needed to be accompanied by the favourable resolution of the municipal council in whose territory the project was foreseen. With the implementation of Directive 2009/28, the Italian legislative framework has been amended, leading to less discretion for the regions: they may only intervene when this is "in favour" of renewable energy sources, thereby promoting the implementation of the legislative targets. The process towards a more coherent approach might culminate in a constitutional amendment recommended by the Italian National Energy Strategy; this would lead to a unified legislation in the energy field and encourage the simplification of the authorization process, in order for national to prevail over local interests.

The situation in The Netherlands, discussed by Kars de Graaf and Albert Marseille, also shows that courts had to be addressed for clarity to be given on the distribution of competences among national and provincial authorities. The Dutch Spatial Planning Act awarded municipalities a general competence to adopt new zoning schemes; provincial and national authorities could use a similar power where there is respectively a special provincial spatial interest or a special national spatial interest to adopt a zoning scheme. However, 
regarding the criteria, the act was apparently not clear enough to divide the competence between the respective administrative levels: the highest administrative court held that a certain spatial interest should be considered national when national policy documents sufficiently explain that it is, and, equally, that a provincial interest should be considered when provincial policy documents imply that it is. In 2009, the competence uncertainty was addressed by a new act which introduced a threshold for national competence: the competence to adopt a land-use plan allowing for wind farms larger than $100 \mathrm{MW}$ was attributed to the national government. Later, in 2010, a threshold was established for provincial competence: the realization of wind farms larger than $5 \mathrm{MW}$ and smaller than $100 \mathrm{MW}$ is considered a special provincial spatial interest, which means that the provincial public authority is competent to adopt a land-use plan allowing for such wind farms. There is even an obligation for the national and provincial government to not merely coordinate the decisions required for the approval of a wind farm, but to take each and every decision that is needed to realize the project itself and to exclude any competence for municipalities. By doing so, the legislature has introduced a one-stop procedure for spatial planning and permits for wind farms larger than $5 \mathrm{MW}$, at least in those cases where the provincial or national government is willing to grant the project initiator's request.

The new legal frameworks in Italy and The Netherlands stand in stark contrast to the position of municipalities in Sweden, where the position of municipalities is constitutionally very strong, resulting in a veto power for municipalities. Gabriel Michanek explains the very specific position of Swedish municipalities thoroughly, and the "blocking" power of these municipalities can only be understood in the history of the constitutional development of Sweden. It is unclear at this moment whether the blocking power of municipalities can be aligned with Article 13 RED. If, however, the European Commission instigated an infringement procedure against Sweden, stating that the blocking power given to municipalities is against the necessity or proportionality requirement of Article 13, it should realize that it is acting against a specific feature of the Swedish constitutional system. This could result in the Swedish people feeling put upon by the European Union. There is an alternative for the Commission through which it could refrain from intervening in the specific constitutional Swedish circumstances: if the Commission concentrated on compliance with the renewable energy target, it would leave it to the Member State to choose how to reach it. If Sweden then ultimately did not comply with its national renewable energy target, it could face an infringement action. The choice how to comply, also in view of the distribution of competences and the power given to municipalities, is then left to the autonomy of Sweden. 
Also in Denmark, where the provincial level has been abandoned, local governments often perform the balancing of the negative local impacts of a renewable energy infrastructure with the more indirect national or global benefits, but there financial mechanisms have been established to overcome negative local effects (Birgitte Egelund Olsen in Chapter 10). In Spain, constitutional complexities exist, and the basic question of who is competent for developing policy and law approaches for promoting renewable energy, is not easy to answer (Chapter 4 by Iñigo del Guayo). Particularly the competences of autonomous communities vis-à-vis the state lead to legal conflicts, for which the Constitutional Court has the final word. While Spain is still a unitary state, increasing signals of a political evolution towards federalism exist, and the distribution of powers between the state and the 17 autonomous communities implies a remarkable decentralization. In a very tentative sense, we conclude that while in some Member States like in Italy and The Netherlands a shift of competences to higher authorities has occurred, at least in some EU Member States, the position of regional authorities and some municipalities is relatively strong, and sometimes surprisingly so. The development of a one-stop procedure, as being promoted by the European Commission, should really be seen in the wider constitutional and socio-legal context that determines the importance of regional governments. In our view, the European Union risks losing citizens' support for EU interventions if they are given the feeling that an abstract and far-away authority has influence over their living circumstances, while their most direct constituency, the local government, cannot properly protect them. Such assumptions require further exploration by socio-legal research.

Further legal research and practical experimentation is certainly needed, since it is not yet clear what the best practices of efficient procedures are. New provisions aiming at expediting procedures must be evaluated. Some early experiences with still new provisions are already available: the quite recent procedural amendments in The Netherlands aiming at coordinating and expediting administrative decision-making are discussed in the chapter by Kars de Graaf and Albert Marseille. They analyse whether the Dutch Crisis and Recovery Act of 2010 has been successful in terms of making procedures faster and more efficient. Interestingly, this Dutch act not only deals with administrative but also with court procedures. The most successful provision, according to De Graaf and Marseille, simply states that courts are obliged to pass judgment within six months. Another more striking example is that access of lower authorities to the administrative courts in procedures against decisions by the national government on specific projects (e.g. renewable energy projects) has been prohibited, and the highest Dutch administrative court has found this legislative provision in accordance 
with international law. Some other important procedural amendments have also been introduced, such as the introduction of the so-called relativity principle (restricting the opportunity for the court to consider substantive claims from citizens). Altogether, the Dutch measures have clearly reduced opportunities for citizens and municipalities. It is necessary to examine more deeply whether such procedural provisions (basically intended to reduce redtape and provide faster procedures to overcome the economic crisis) ultimately lead to a faster development of renewable energy, and, if so, how detrimental they might be to citizens' support of this transition. Ultimately, there will be a new chance for citizens to vote, and if they are uncomfortable with the non-consideration of local concerns, new governments may be elected, who may - in turn - alter the legislative framework.

\subsection{Veto}

In contrast to what has happened in the Netherlands, where some competences have been placed at national or provincial level and where municipalities cannot address the administrative courts for specific projects, among which are large renewable energy projects, Swedish municipalities have a strong position culminating in a veto power. This would be unthinkable for Italy, where a provision introduced by a Region entailing that renewable energy should only be allowed after municipality consent has been rejected by the Constitutional Court.

The Swedish veto applies in connection with permitting wind power installations only, no other types of "environmentally hazardous installations", such as factories or mines. Moreover, the veto is unfavourable for wind power development in competition with other forms of energy industry for which a general municipal veto, in connection with permitting, does not exist. Since the veto does not cover hydro installations, one can ask whether this is in compliance with the principle of equality as a fundamental principle of EU law and the requirement of Article 13 RED that procedures not discriminate between applicants. Both principles have been considered by the Court of Justice of the European Union in the Puglia Windfarm case (Case C-2/10, para 64-75). The CJEU stated that the principle of proportionality must also be examined in view of the fact that a specific measure is confined to wind power plants and does not extend to other forms of renewable energy production (in the Puglia case, a prohibition of commercial wind power in a Natura 2000 area is only confined to wind power plants, see para. 74). Although the CJEU in its preliminary decision does not determine in detail whether the principle of equality or the principle of 
proportionality allows for a differential treatment of wind power plants, one can see that, depending on the circumstances, discrimination of a specific type of renewable energy plants in favour of other renewable energy plants may not always be in conformity with EU law. Particularly in the case of Sweden, energy operators could argue that the veto applicable for only wind energy production is in breach of EU law, which could eventually lead to a preliminary question to the CJEU. As Gabriel Michanek argues, in a Swedish permit case, it is not possible to interpret the veto in conformity with the RED (particularly Article 13) as the Swedish provision is clearly formulated and does not provide for any discretion. The Swedish practice could be subject to a reaction from the EU Commission, possibly leading to an infringement procedure where the legality of the veto, with regard to EU law, can be assessed. This would eventually lead to questions of state liability if the veto were deemed to be in contravention of EU law, although it is uncertain that judges would find that Article 13 confers rights to the energy operators.

Interestingly, Michanek points at the fact that it has been argued in Swedish legal literature that a municipality cannot use its competence in an "indecent" way, which would be the case if a municipality requires (inordinate) economic or other benefits from the wind power investor as a condition for agreeing to the permit. This links to the discussion of how to establish local community financial participation in the business of wind power generation, as discussed in several chapters in this book and in Section 3.2 of this concluding chapter. Most likely, in Sweden, a legislative amendment is needed to allow for financial participation to wind energy projects.

\section{Conclusion and research outlook}

\subsection{The Role of Regional Governments for Renewable Energy: Research Themes}

It is not self-evident that local communities will have a positive attitude towards renewable energy activities either in or near their territory, particularly if they do not benefit financially from the commercial renewable energy production. Regional authorities often have important powers for the authorization of renewable energy activities, such as spatial planning decisions and environmental or nature conservation permits. Within this decision-making, a delicate balance may have to be made between, for instance, ecological protection and hydropower production, or between local resistance arising from the fear of loss of property value and the global need for greenhouse gas reductions. Regional governments are entities vested in generally important decision-making powers for the energy transition, but also where 
resistance can be felt to the establishment of renewable energy activities. This book has learnt that further research is needed, in particular legal comparative and empirical research, in order to develop best practice models for information, administrative decision-making, and financial provisions. Alongside these focal points, there is a pressing need to examine more deeply how EU and national legislation, including national renewable energy planning and national support measures, heed the concerns of local governments.

\subsection{NIMTOO or YIMTOO?}

It will be interesting to examine under what circumstances regional governments employ positive attitudes towards the necessary energy transition. Most strikingly, it might be the case that a number of regional governments follow a NIMTOO approach: Not In My Terms Of Office. ${ }^{22}$ Strong citizens' opposition against renewable energy in their neighborhood may influence local politicians, who might adopt such resistance with a view of getting re-elected. It might therefore be necessary to generate special legal approaches towards regional governments in order to overcome the NIMTOO effect, including incentives such as tax arrangements providing financial benefits if renewable energy is generated within the territory, or establishing a legal obligation for regional governments to designate land for renewable energy projects. Citizens can be directly targeted as well, for instance with proper information and timely opportunities to participate in governmental decision-making. These approaches will probably not be sufficient to overcome NIMBY, which leads to considering enabling citizens to participate financially, and providing them with sufficient compensation from the energy business - and, most likely, ultimately the energy consumers. These new approaches for financial citizen participation and compensation must be carefully examined, not only including potential price effects on renewable energy generation, but also as to how these approaches could overcome the NIMBY effect. As is common practice in legal research, a balanced and inclusive approach should be taken: for instance financial measures, like providing regional governments with a substantial amount of tax revenues from renewable energy production in their territory, might motivate local politicians to display a positive attitude towards renewable energy projects. Hence, a conflict of interest may emerge: the institution that decides on renewable energy accrues at the same time income. This could endanger the correct application of procedures aiming to guarantee the rights of third persons. Here, the question is what exercises the stronger influence over local politicians: citizens'

\footnotetext{
${ }^{22}$ To contrast with NIMTOO, one could speak of YIMTOO: "Yes In My Terms Of Office".
} 
protest from a limited number of inhabitants against the establishment of renewable energy installations, or financial profit for the whole community from tax revenues. This is just one example showing the need for further exploration into the effects of new models addressing NIMTOO and NIMBY. Another option to be explored is the shift of administrative decisionmaking towards higher governmental levels, which would, in a formal sense at least, decrease the power of local governments to prevent the establishment of renewable energy in their territory, although such redistribution of competences may meet constitutional constraints.

\subsection{Building a Stable Framework while Learning and Experimenting}

Frequent changes of the regulatory framework for renewable energies, and particularly of national support measures, may create legal uncertainty and cause governmental and business costs when adopting the new rules. On the other hand, not even the research community seems to have a template providing an ideal model for a law that would steer society smoothly, justly and efficiently towards the 20 per cent renewable energy target for 2020, and particularly not in the multi-level setting of the European Union. The regulatory framework for climate and energy in the EU is complex and consists of several instruments, which means that the appropriateness of EU renewable energy regulation cannot be assessed in isolation. The interplay between instruments, particularly that between the EU emissions trading scheme, the Renewable Energy Directive and the Energy Efficiency Directive must be well understood and coordinated. We must accept that, to some extent, regulatory experimental attempts to steer towards a sustainable energy society are vital, and that good and lesser regulations may appear along the way. Courts will not always be able to correct "malregulation": exemplary is the Spanish case discussed by Iñigo del Guayo in which the Supreme Court admits that, although the regulation chosen by the government is poor, such regulation is not necessarily illegal. Nonetheless, specifically for authorizations of renewable energy installations, including the application of Aarhus rights such as access to information, to governmental decision-making and to courts, we expect case law to become increasingly important in the field of renewable energy law. Regional governments will more and more often be part of this development. There is certainly a need to engage in further comprehensive research in regional renewable energy by providing a systematic analysis of legal problems and related court cases the regional governments in EU Member States must deal with. 


\section{REFERENCES}

Cole, Daniel H. (2011), "From Global to Polycentric Climate Governance", 2 Climate Law 395-413.

Desmet, Ellen (2010), 'Balancing Conflicting Goods. The European Human Rights

Jurisprudence on Environmental Protection", 7(3) Journal on European Environmental and Planning Law 303-23.

Ekardt, Felix, Stefan Klinski and Thomas Schomerus (2014), Konzept für die Fortentwicklung des deutschen Klimaschutzrechts, Umweltbundesambt, (in preparation).

Fraunhofer Institute for Solar Energy Systems, Levelized Cost of Electricity Renewable Energy Technologies, 2013, accessed 27 August 2014 at

www.ise.fraunhofer.de/en/publications/veroeffentlichungen-pdf-dateien-en/studien-undkonzeptpapiere/study-levelized-cost-of-electricity-renewable-energies.pdf.

Peeters, Marjan (2014), "Instrument mix or instrument mess? The administrative complexity of the EU legislative package for climate change", in: Marjan Peeters and Rosa Uylenburg (eds.), EU environmental legislation, Cheltenham, UK and Northampton, MA, USA: Edward Elgar. 